УДК 159.964.2:616.895.8

DOI:10.26565/2410-1249-2018-10-03

\title{
PSYCHOTHERAPEUTIC CHARACTERISTICS OF SCHIZOID PERSONALITY
}

\author{
Yulia Svynarenko \\ National Aerospace University - "Kharkiv Aviation Institute" \\ Chkalova street, 17, Kharkiv, 61070, Ukraine \\ E-mail: svinarenko.y@gmail.com, https://orcid.org/0000-0001-5302-6480
}

The article describes the features of psychotherapeutic work with schizoid topic. An understanding of the schizoid psyche in the practical phenomenological direction is considered exclusively under the psychological norm. The main internal conflict of schizoid is described.It shows the strong need for close relationships and the inability to feel comfortably in this proximity. The characteristics of emotional, behavioral, and rational spheres of schizoid individuals are briefly examined. Attention is drawn to features and strategies of psychotherapeutic work with such clients. The first strategy of psychotherapy for a schizoid personality is to create the necessary atmosphere of trust and support, a sense of security in contact with a psychotherapist. The next strategy is to satisfy the demand of a schizoid client to be unconditionally accepted with his unique subjective experience. It is investigated the need for openness and congruence on the part of a therapist. A client in trustful contact with a psychotherapist can recognize his emotional experiences that are unconscious and discarded. Confirmation and reflection of personal feelings in contact with a psychotherapist is sanogenic for a schizoid client. A body-oriented strategy of schizoid-type psychotherapy is considered. The features of the schizoid bodily organization are to block the energy impulses in the muscles. Emotional experiences are disabled due to muscle expression, significant limitation of vital energy in the body. The task of a therapist is to maximally ecologically and fundamentally expand the consciousness of the client to accept personal emotions, needs, experiences and impulses of the body. Client must be ready for a therapist to apply bodyoriented techniques. The variants of psychotherapeutic mistakes in work with schizoid dynamics are noted.

KEY WORDS: psychotherapy, schizoid character, personality.

\section{ОСОБЕННОСТИ ПСИХОТЕРАПИИ ЛИЧНОСТИ С ШИЗОИДНЫМ ХАРАКТЕРОМ}

Свинаренко Ю.В.

Национальный аэрокосмический университет им. Н. Е. Жуковского «Харьковский Авиационный Институт»

ул. Чкалова, 17, г. Харьков, 61070, Украина

В статье представлены особенности психотерапевтической работы с шизоидной проблематикой. Рассмотрено понимание шизоидной организации психики в практически феноменологической направленности, исключительно в рамках психической нормы. Описан основной внутренний конфликт шизоида, который заключается в крайней необходимости близких отношений и неспособности комфортно чувствовать себя в этой близости. Кратко рассмотрена характеристика эмоциональной, поведенческой и рациональной сфер шизоидно организованных личностей. Выделены особенности и стратегии психотерапевтической работы с такими клиентами. Первая стратегия психотерапии шизоидной личности заключается в создании необходимой атмосферы доверия и поддержки, ощущении безопасности в контакте с психотерапевтом. Следующая стратегия выражается в том, чтобы удовлетворить потребность шизоидного клиента в безусловном принятии его уникального субъективного опыта. Аргументирована необходимость открытости и конгруэнтности со стороны психотерапевта. Клиент в доверительном контакте с психотерапевтом может узнать свои эмоциональные переживания, которые являются неосознанными и отвергнутыми. Подтверждение и отражение собственных чувств в контакте с психотерапевтом является саногенным для шизоидного клиента. Рассмотрена телесноориентованная стратегия психотерапии шизоидного характера. Особенности телесной организации шизоида заключаются в блокировании энергетических импульсов в мышцах. Эмоциональные переживания блокируются через экспрессию мышц, значительная ограниченность жизненной энергии в теле. Задача психотерапевта максимально экологически и фундаментально расширить сознание клиента по принятию собственных эмоций, потребностей, переживаний и импульсов тела. Применяя телесно-ориентированные техники, психотерапевт должен чувствовать готовность клиента к этому. Рассмотрены возможные варианты психотерапевтических ошибок в работе с шизоидной динамикой.

КЛЮЧЕВЫЕ СЛОВА: психотерапия, шизоидный характер, личность

\section{ОСОБЛИВОСТІ ПСИХОТЕРАПІЇ ОСОБИСТОСТІ 3 ШИЗОЇДНИМ ХАРАКТЕРОМ}

Свинаренко Ю.В. Національний аерокосмічний університет ім. М. С. Жуковського «Харківський авіаційний інститут» вул. Чкалова 17, м. Харків, 61070, Україна

У статті представлено особливості психотерапевтичної роботи з шизоїдною проблематикою. Розглянуто розуміння шизоїдної організації психіки у практично феноменологічній направленості, виключно в рамках психічної норми. Описано основний внутрішній конфлікт шизоїда, який полягає у гострій потребі близьких стосунків та нездатності комфортно відчувати себе у

(C) Svynarenko Yu., 2018 
цій близькості. Стисло розглянуто характеристику емоційної, біхевіоральної та раціональної сфер шизоїдно організованих особистостей. Виділено особливості та стратегії психотерапевтичної роботи з такими клієнтами. Перша стратегія психотерапії шизоїдної особистості полягає у створенні необхідної атмосфери довіри та підтримки, відчутті безпеки у контакті з психотерапевтом. Наступна стратегія виражається у тому, щоб задовольнити потребу шизоїдного клієнта у безумовному прийнятті його унікального суб'єктивного досвіду. Необхідність відвертості та конгруентності 3 боку психотерапевта. Клієнт у довірливому контакті з психотерапевтом може упізнати свої емоційні переживання, які $\epsilon$ неусвідомлені та відкинуті. Підтвердження та віддзеркалення власних почуттів у контакті з психотерапевтом є саногенним для шизоїдного клієнта. Розглянуто тілесно-орієнтовану стратегію психотерапії шизоїдного характеру. Особливості тілесної організації шизоїда полягають у блокуванні енергетичних імпульсів у м'язах. Емоційні переживання блокуються через експресію м'язів, значна обмеженість життєвої енергії у тілі. Завдання психотерапевта максимально екологічно й фундаментально розширити свідомість клієнта щодо прийняття власних емоцій, потреб, переживань та імпульсів тіла. Застосовуючи тілесно-орієнтовані техніки психотерапевт повинен відчувати готовність клієнта до цього. Розглянуто можливі варіанти психотерапевтичних помилок у роботи з шизоїдною динамікою.

КЛЮЧОВІ СЛОВА: психотерапія, шизоїдний характер, особистість

The topic of schizoid personality can be considered from two positions in psychotherapeutic practice. The first variant to understand the radical of schizoid personality incorporates the method of the Diagnostic Statistic Manual (DSM-IV) used by the American Psychiatric Association. It is the baseline for the diagnosis and classification of characters and the narrative psychiatric taxonomy. Another approach to understand the schizoid organization of mindhas practically phenomenological direction exclusively within the framework of the psychological norm. This conceptis presented in the work of Nancy McWilliams, who defines schizoid as "complexity of inner mental lifein personality" (McWilliams, 2006).

According to DSM-IV, a schizoid identity is indifferent to the proximity (McWilliams, 2004) interprets schizoid using the theory of object relations. The conflict of desire for intimacy and avoidance is specific for such a person. The use of the term "schizoid" in psychoanalysis originates from observations of the disjuncture between the inner and outer life of an individual. The antisocial behavior of schizoid personality is a protective strategy to avoid hyperstimulation and traumatic experience of close relationships. Such people keep the distance in contact, while they have an inner thirst for affinity and vivid imaginations of psychological intimacy.

People with schizoid mental dynamics are common in psychotherapeutic practice (McWilliams, 2006). At the same time, such clients are represented by a wide variety of standardsin mental and emotional health: from the borderline level with single psychotic episodes to a stable psyche with non-adaptive behavior strategies. According to N. McWilliams, even against the background of serious problems of psychological intimacy and proximity, the majority of highly effective schizoid individuals are characterized by positive aspects of the mental functioning (life satisfaction, feeling of self, constant ego and object, creativity). The main internal conflict of schizoid is the critical need for close relationships and the inability to feel comfortably in this proximity. A person of this kind feels safe with a very small number of people. Any threat or real loss of such relationships is destructivefor integrity and power of schizoid. Since the schizoid personality is characterized by a complex and long-lasting precontact, like a verification of trust, the loss of an already established close relationship with another is tragic and devastating to them (Guntrip, 1969).

A schizoid type of personality usually reaches out for psychotherapeutic assistance in the case of loss of meaningful close relationships or for a specific purpose - to develop certain communicative skills, to engage in romantic relationships, etc. In the first case, we are talking about the exhausted Ego which is not able to cope with the reduction of anxiety and internal pain from desolation and loneliness. In the second case, on the contrary, the question is in a more adaptive state of the psyche and a greater ability to form a therapeutic alliance with a psychotherapist.

Let's consider the characteristics of emotional, behavioral and rational spheres of schizoid-organized individuals (Johnson, 2001). Preverbal assimilation of traumatic experience leads to devastating tendencies of the personal integrity. General anxiety and stress inherent in schizoid individuals are associated with social 
situations and intimacy. Subjectively, traumatic situations are triggers for activating the psychological defense of personality.

A person with schizoid problem is foreseeable and with a certain mechanical manner in the manifestation of emotions. There is an inability to experience anger and to perceive it from others. Usually the psyche of schizoid identitydisplaces its own anger and personality begins to idealize itself. Feelingsof sadness, mourning and depressed mood become the most common symptoms of schizoid personality. Those emotions are the least depressed, but at the same time they are inactive in the body. Such feelings are allegedly experienced in the form of long-term or chronic depressive states (characterized by escape from reality and facile self pity). In other words, schizoid does not fully understand or experiences no worry even in such negative emotional states. A schizoid person tends to dive into a certain particular activity and develop only in one sphere. For example, workaholism, success in a career, is characterized by isolation in intimate relationships. In interpersonal relationships, there is an escape from direct confrontation or psychological intimacy (Guntrip, 1969).

For schizoid, exposure in intellectual processes and external achievements serve as a safe support, protecting from unpredictability of life. Since such a person is not able to identify himself with body life and develop this stable feeling, he is forced to seek support beyond reality by running into intellectual space and imagination. The desire to obtain approval precisely according to intellectual achievements is in evidence for them. In close relationships, schizoids constantly regulate the breadth and depth of contacts in order to maintain a sense of their own security. Such behavior is compulsory because a schizoid person perceives it as a struggle for life.

The separation of intellectual processes and the senses keeps mental functions from unwanted emotional connotation. The result of schizoid trauma and early developmental constraints has the role of "freezing" the body. The unconscious purpose of this is to control the strong negative emotions. In a situation of social communication, a schizoid can look quite self-sufficient. However, such people are characterized by an extremely strong need for acceptance and understanding of their inner world. From the outside, they seem out of touch, experiencing a lack of emotional warmth. It feels as if schizoid is emotionallyretarted, but there is a terrible experience of flooding by the intense emotions inside him (Kuznetsov, 2010).

The general concept of the psycho-therapeutic work with schizoids is to create an atmosphere of trust and support (McWilliams, 2004). A client should form a stable sense of security in psychotherapeutic contact. A psychotherapist at the initial sessions must avoid invasion to the intimate space of a client's psyche, which is so strictly guarded by Ego. It is worthwhile to avoid the temptations of analyzing the client's protective mechanisms and interpretations, since such early interventions can be traumatic. The tempo of psychotherapy should be fully consistent with the schizoid dynamics of each individual client.

It is because of the necessary safety condition in contact for the disclosure of patient the client-centered psychotherapy is effective to deal with schizoid problems. The classic version of psychoanalysis in the method of free association is also widely used and considered effective, since it provides space for the development of client's reflectivity.

One of the global challenges in schizoid therapy is to establish the ability to distinguish, recognize and accept personalfeelings. Problem solving is an area for demonstration of creativity and gumption of therapist. It is needed to reach repressed emotions by using non-standard, individualized ways. These are the emotions that are threatening the integrity of client's Ego. Let's consider several options. (McWilliams, 2006) gives an example from her own practice: "One of my clients, who mostlyhad to take a grip on herself to talk, once called me in tears. "I need you to know that I want to talk to you! - she said, - but it is very painful for me ... ". As a result, we achieved therapeutic progress in a rather non-standard way - I read aloudthe understandable and least humiliating psychoanalytic literature about schizoid psychology and asked if this description coincided with her subjective experience. "This example illustrates the emotional expression of passion 
through intellectual means. That is, when the client is not able to recognize his own emotional experiences, the necessary auxiliary, alternative techniques are needed.

The effective way of work with the problem of identifying personal emotions by patient is the subverbal model of client-centered psychotherapy of (Kocharyan, 2014). The idea of this model shows that it is impossible to enter into the depth of experience only through conversation and words. The freedom from priority of a word in experimental psychotherapy consists of a discrepancy in the meaning of the word, as a wrapping, and emotion, asa candy. Kocharyan O.S. in his articles notes the importance of sensitivity of a therapist to subverbal bodily experience ofa client (experimental reflection). "Subverbal experience has the quality of fluidity, variability, while modalized verbal experiences that are associated with an injury, and in this context are "plug"experiences, on the contrary, do not have the quality of fluidity, they are "stuck", turned into "crystal"that rests in the body like a thing, they are conscious or close to awareness, they do not arise and do not disappear - they are always present, either in actual or in potential forms, they are resistant to psychotherapeutic influence." Such an approach to psycho-therapeutic work with schizoid issues allows us to go round the protective mechanism of intellectualization and help the client to focus on the emotional experiences.

The next important feature of the psychotherapy of schizoid personality is the strong need to accept and understand the uniqueness of client's subjective experience (Johnson, 2001). The feelings of person who isunderstood and accepted arises from the discovery of the personal experience of a therapist. Self-realization, openness and appealing to personal emotional background- the strategy of a therapist which is necessary in such cases. A client in trustful contact with a psychotherapist can recognize his emotional experiences that are unconscious and discarded. Internal fear of confrontation with personal emotions and affects, which is typical for such clients, can be solved in this way.

Confirmation and mirroring of personal feelings in contact with a psychotherapist is sanogenic for a schizoid client. The experience of a client "One understands me and there is nothing to threaten me with" is the goal at this stage of the psychotherapeutic process. Schizoids are very afraid to be in the center of attention of others, especially because of their own extraordinary. For them, there is a strong fear that personal originality and high sensitivity will be perceived as abnormal, pathology. Fear that one will not accept and will not understand themmay causeunsociable demeanour. Even highly organized individuals with a schizoid radical are inherent in their own normality. (McWilliams, 2004) explains the schizoid's fear to appear in the field of pathology by his projection of belief in the intolerance of internal experience. In other words, such an experience is unrecognizable neither by the person itself nor by others.

A body-oriented strategy in psychotherapy of schizoid nature (Kuznetsov, 2010) deserves particular attention. According to the ideas of A. Lowen, a certain muscular armor corresponds to the structure of the character. The features of the bodily organization of schizoid are to block the energy impulses in the muscles. Emotional experiences are closed due to muscle expression, significant limitation of vital energy in the body. The movements seem constrained, mechanical, deprived of spontaneity and expression. Schizoid personality has the following physical manifestations: chronic tension in the neck, caused by a disconnection in thinking and feelings; limitation and constrain of breathing in the upper part of the chest; spinal curvature as an illustration of escape and detachment from others, eye block, etc.

Integrative strategy of combining the body-oriented and psychoanalytic techniques is effective at the stage of establishing contact with the body and "enabling" the energy resources of the client's corpus. Bodyoriented techniques, which are not accompanied by exercises for the realization of blocked emotional experiences, will bring short-term results. The task of a therapist is to expand consciousness of a client maximally ecologically and fundamentally to accept personal emotions, needs, experiences and impulses of the body. The prosperity of psychotherapy depends on how successful the schizoid seduction will be resolved. 
Fear and desire for a contact - is a steady characteristic of such clients. The demonstrative distance in a contact involves a strong desire for closeness to others and fears at the same time. Therefore, when using a body-oriented technology, a therapist should feel client's readinessfor it.

From description of the practice in psychotherapy of schizoid, it is known that such clients are characterized by high sensitivity to the unconscious feelings of others and a therapist (McWilliams, 2004). A schizoid personality has a strong empathy, he feels others perfectly, but is not able to express it in contact. If a therapist is uncertain about his actions regarding a client and he is afraid to touch the body incorrectly, then a schizoid perceives it as his personal disadvantage. Thus, the bodily touch in schizoid psychotherapy is an extremely important and difficult moment. After all, such a client has a strong desire to be accepted (through a physical contact as well), and at the same time he has an overwhelming fear of being rejected (repetition of traumatic infantile experience) (Kuznetsov, 2010).

Psychotherapy of schizoid personality requires a great deal of consciousness and congruence of a psychotherapist himself. This can be compared to the walk above the steep-one false, unseasonable action and the trust in contact disappears. The biggest risk in psychotherapeutic work with such clients is the delayed intensification of emotions and their awareness. An extremely emotionally directed psychotherapist, who does not take into account the importance of the intellectual sphere when dealing with a schizoid person, risks to put the client in an immature, unconstructive experience of emotive experience and repeated traumatization of the psyche. The lowspeed psychotherapeutic process amongschizoidal clients requires patience from a therapist. Another version of the failurein psychotherapy is too emotionally restrained and rational therapist who goes into a field of solid intellectualization. Thereby he increasesthedistance witha client.

As a result, the peculiarities of psychotherapeutic work with schizoid personality are to create an atmosphere of trust and support in contact with a psychotherapist; satisfy the need of schizoid client toaccept unconditionally his unique subjective experience; the necessity for openness and congruence on the part of a therapist; expand the client's consciousness about accepting his own emotions, needs, experiences and impulses of the body in a maximally ecological and fundamental way.

\section{REFERENCES}

Dzhonson, S.M. (2001). Психотерапия характера. Методическое пособие для слушателей курса «Психотерапия» [Psychotherapy character. Methodological guide for students of the course "Psychotherapy"]. Moskva: Centr psihologicheskoj kul'tury. (in Russian)

Guntrip, H. (1969). Schizoid phenomena, object relations and the self. NewYork: International Universities Press.

Kocharyan, A.S. (2014). Переживание как мишень клиент-центрированной психотерапии. [Experiencing as the target of client-centered psychotherapy] Psychological counseling and psychotherapy, 1-2. 24-36. (in Russian)

Kuznetsov, S. (2010). Теория и практика работы с шизоидной структурой личности в телесно-ориентированной ncuxomepanuu. [Theory and practice of working with the schizoid personality structurein body-oriented psychotherapy] (inRussian). Retrieved from https://www.integratio.art/files/schizoid-book.pdf

McWilliams, N. (2004). Psychoanalytic psychotherapy: A practitioner'sguide. NewYork: Guilford Press.

McWilliams, N. (2006). Some Thoughts about Schizoid Dynamics. The Psychoanalytic Review, 93(1). 1-24. 